\title{
Jurnal Ilmu Kehutanan
}

Journal of Forest Science

https://jurnal.ugm.ac.id/jikfkt

\section{Status Ergonomi Pekerja Sektor Kehutanan di Indonesia: Kelelahan Fisik-Mental-Sosial, Kepuasan Kerja, Konsep Sumber Bahaya, dan Konsep Biaya Kecelakaan}

Ergonomics Status of Indonesian Forestry Workers: Physical-Mental-Social Fatigue, Job Satisfaction, Concept of Hazards, and Concept of Accident Cost

\section{Efi Yuliati Yovi}

Departemen Manajemen Hutan, Fakultas Kehutanan, Institut Pertanian Bogor Kampus IPB Dramaga PO Box 168, Bogor, 1668o

Email: eyyovi@apps.ipb.ac.id

\section{HASIL PENELITIAN}

Riwayat Naskah :

Naskah masuk (received): 6 Februari 2019

Diterima (accepted): 11 Juli 2019

\section{KEYWORDS}

forest management

forest ergonomics

risk management

MSDs

OSH protection

\begin{abstract}
Sustainable forest management requires attention to the protection of occupational safety and health (OSH), in addition to attention to aspects of work productivity, and the welfare of managers/ workers. In Indonesia, these four aspects, which are the main objectives of ergonomics studies, have not received much attention, although forest management activities are activities with a high risk of OSH disorders. This study aims to present an overview of the conditions of physical-mental-social fatigue, musculoskeletal disorders (MSDs), job satisfaction, perception of hazards sources, and perception toward work accident costs from workers involved in forest management activities in Indonesia. Fatigue status was measured using the Cumulative Fatigue Symptom Index (CFSI) and MSDs were investigated using Standardized Nordic Questionnaire (SNQ). Job satisfaction, perception of the source of danger, and the cost of accidents were traced using questionnaires and interviews (face to face, open and semi-structured questions). Data were taken from 98 respondents consisting of forest rangers, forest inventory workers, logging supervisors, and administrative staff during February 2016-October 2017. The CFSI analysis shows that forest guarding and forest inventory have caused intense physical and mental fatigue (in the form of excessive anxiety). The SNQ analysis confirms intense MSDs complaints at the waist, back, neck, shoulders, and arm. The general characteristics of the respondents were having: (1) limited financial capacity, (2) inadequate knowledge to recognize various potential hazards sources at work, and (3) inappropriate understanding of the concept of accident costs. The limitations on the respondents' cognitive, has made participatory $\mathrm{OSH}$ mechanisms alone (to improve OSH protection) is not an appropriate option. Efforts to improve OHS protection should be carried out in the form of (1) improving workplace facilities (health facilities, social and communication facilities, accessibility), (2) improving remuneration, and (3) improving knowledge on the concepts of the source of hazards and accident cost.
\end{abstract}




\section{INTISARI}

\section{KATA KUNCI}

pengelolaan hutan ergonomi kehutanan manajemen risiko

MSDs

perlindungan $\mathrm{K}_{3}$
Pengelolaan hutan lestari menuntut perhatian terhadap perlindungan keselamatan dan kesehatan kerja $\left(\mathrm{K}_{3}\right)$, selain perhatian terhadap aspek produktivitas kerja, dan kesejahteraan pengelola/pekerjanya. Di Indonesia, ke-empat aspek tersebut, yang merupakan tujuan utama kajian ergonomi, belum banyak mendapat perhatian, walau kegiatan pengelolaan hutan merupakan kegiatan dengan risiko gangguan $\mathrm{K}_{3}$ yang tinggi. Penelitian ini bertujuan untuk menyajikan gambaran kondisi kelelahan fisikmental-sosial, gangguan otot, kepuasan kerja, persepsi terhadap sumber bahaya, dan persepsi terhadap biaya kecelakaan kerja dalam kegiatan pengelolaan hutan di Indonesia. Status kelelahan diukur menggunakan instrumen Cumulative Fatigue Symptom Index (CFSI) dan gangguan otot diinvestigasi menggunakan instrumen Standardized Nordic Questionnaire (SNQ). Kepuasan kerja dan persepsi terhadap sumber bahaya dan biaya kecelakaan ditelusuri menggunakan kuisioner dan wawancara (tatap muka, pertanyaan terbuka dan semi terstruktur). Data diambil dari 98 responden yang terdiri atas polisi hutan, tenaga inventarisasi hutan, pengawas/mandor penebangan, dan staf administrasi selama Februari 2016-Oktober 2017. Analisis CFSI menunjukkan bahwa kegiatan penjagaan hutan dan inventarisasi hutan telah menyebabkan gangguan kelelahan fisik dan mental yang intens (dalam bentuk gangguan kecemasan). Analisis SNQ mengonfirmasi keluhan gangguan otot pada pinggang, punggung, leher, bahu, serta lengan (bawah-atas). Secara umum responden memiliki (1) keterbatasan secara finansial, (2) tingkat pengetahuan yang belum memadai untuk mengenali berbagai sumber bahaya potensial di tempat kerja, dan (3) pemahaman yang kurang tepat terhadap konsep biaya kecelakaan. Keterbatasan aspek kognitif responden menyebabkan penggunaan mekanisme $\mathrm{K}_{3}$ partisipasif semata (untuk meningkatkan perlindungan $\mathrm{K}_{3}$ ) bukanlah keputusan yang tepat. Upaya peningkatan perlindungan $\mathrm{K}_{3}$ perlu dilakukan dalam bentuk (1) peningkatan fasilitas kerja (fasilitas kesehatan, saranasarana sosial dan komunikasi, aksesibilitas), (2) peningkatan pendapatan, dan (3) peningkatan pemahaman terhadap konsep sumber bahaya dan konsep biaya kecelakaan kerja.

\section{Pendahuluan}

Konsep pengelolaan hutan lestari (sustainable forest management) tidak saja mensyaratkan kecukupan perhatian pada aspek "manajemen hutan" (pengelolaan) serta "hutan" sebagai objek pengelolaan. Konsep ini juga mensyaratkan perhatian serius terhadap aspek "manusia" tidak saja sebagai penerima manfaat, melainkan juga sebagai pelaksana kegiatan pengelolaan itu sendiri (UN 1992).

Kegiatan pengelolaan hutan dikenal memiliki tingkat risiko gangguan $\mathrm{K}_{3}$ yang tinggi terhadap pekerja yang terlibat. Sebagai contoh, aktivitas

(C) Jurnal Ilmu Kehutanan-All rights reserved

fisik penebangan tidak hanya membebani operator chainsaw dengan beban kerja fisik yang tinggi, namun juga teridentifikasi memberikan masalah ergonomi lainnya karena postur kerja canggung yang berkontribusi terhadap gangguan otot (muskuloskeletal disorders; MSDs) (Gallis 2006; Barbosa et al. 2014; Yovi \& Prajawati 2015) pada punggung bagian bawah, lengan, dan pergelangan tangan. Analisis kualitatif-subjektif terhadap postur kerja menggunakan teknik Rapid Entire Body Assessment (REBA; Hignett \& McAtamney 20oo) terhadap operator chainsaw yang terlibat dalam kegiatan tebang habis tegakan Acacia mangium 
(berdiameter kecil, 18-20 cm) mencatat potensi tingkat risiko terjadinya cidera otot pada skala risiko 4 (nilai maksimum pada skala adalah 5) (Yovi \& Prajawati 2015). Selain itu, berbagai penelitian yang dilakukan terhadap operator alat berat pemanenan seperti alat sarad, tree-harvester, dan feller bucher juga membuktikan adanya gangguan kesehatan kerja yang serupa (Rehn et al. 2009; Silva et al. 2014).

Dalam kegiatan pengelolaan hutan yang berisiko tinggi, gangguan kesehatan berupa stres akibat tekanan pekerjaan, rendahnya kepuasan kerja dan produktivitas kerja, merupakan isu yang juga sangat penting. Arshadi dan Damiri (2013) menyebutkan bahwa stres akibat pekerjaan memberikan pengaruh negatif terhadap kinerja, yang pada akhirnya akan menurunkan tingkat produktivitas kerja dan meningkatkan gangguan $\mathrm{K}_{3}$ akibat melemahnya iklim keselamatan (safety climate). Di sisi lain, pekerja yang menyatakan puas terhadap kerja dan tempat kerjanya memiliki persepsi positif terhadap safety climate (Gyekye 2005). Gyekye (2005) juga menyatakan bahwa pekerja yang puas terhadap pekerjaan dan tempat kerjanya memperlihatkan komitmen yang lebih tinggi terhadap kebijakan manajemen keselamatan kerja sehingga mereka lebih sedikit terlibat dalam kecelakaan kerja.

Informasi terkait kondisi kelelahan fisik-mentalsosial, keluhan gangguan otot, kepuasan kerja, serta persepsi pekerja terhadap sumber bahaya dan biaya kecelakaan kerja dalam beberapa kegiatan pengelolaan hutan di Indonesia, khususnya untuk level operator lapangan (operator chainsaw, asisten operator, operator alat berat, dan sopir truk logging), telah tersedia (Yovi \& Yamada 2019), namun informasi serupa untuk kelompok pekerja polisi hutan, pekerja inventarisasi hutan, pengawas penebangan, dan staf kantor/administrasi belum tersedia. Di sisi lain, informasi kondisi dan gangguan $\mathrm{K}_{3}$ diperlukan oleh pengambil keputusan dalam merumuskan strategi yang tepat bagi perlindungan $\mathrm{K}_{3}$, optimalisasi produktivitas kerja, dan peningkatan kualitas hidup pekerja kehutanan. Strategi yang disusun berdasar informasi tersebut sangat diperlukan sebagai salah satu syarat penting tercapainya tujuan pengelolaan hutan produksilestari secara paripurna. Hal ini berarti bahwa penelitian untuk menyediakan informasi ergonomi pada kelompok pekerja selain operator lapangan menjadi sangat penting. Oleh karena itu, penelitian ini bertujuan untuk mengupas kondisi dan gangguan $\mathrm{K}_{3}$ khususnya kelelahan dan gangguan otot, kepuasan kerja, serta persepsi pekerja terhadap sumber bahaya dan biaya kecelakaan pada kelompok penjaga hutan/polisi hutan, pekerja inventarisasi hutan, pengawas penebangan (supervisor/mandor tebang), dan staf kantor/administrasi yang memiliki karakteristik kegiatan dan lingkungan kerja berbeda dengan kelompok operator. Selain itu, mengingat kepuasan kerja memberikan pengaruh positif yang nyata terhadap kinerja dan produktivitas kerja (Tumen \& Zeydanli 2016; Shobe 2018), penelitian ini juga bertujuan untuk mengupas faktor-faktor yang dapat mempengaruhi kepuasan kerja secara positif.

\section{Bahan dan Metode}

\section{Waktu dan lokasi penelitian}

Penelitian ini dilakukan pada Februari 2016 hingga Oktober 2017. Seluruh responden dipilih secara acak dari 6 unit pengelolaan hutan ( 2 unit bergerak dalam pengelolaan hutan alam di Pulau Kalimantan, dan 4 lainnya bergerak dalam pengelolaan hutan tanaman berdaur panjang di Pulau Jawa).

\section{Bahan dan alat}

Penelitian ini melibatkan 98 responden pekerja kehutanan (pekerja tetap) yang dipilih secara acak dari kelompok polisi hutan (15 responden, seluruhnya bekerja di hutan tanaman berdaur panjang di Pulau Jawa), pekerja inventarisasi hutan (15 responden), pengawas penebangan (47 responden), serta staf kantor/administrasi (berkantor di base camp; 21 responden). Data yang diambil meliputi data yang menggambarkan status kesehatan pekerja (terutama terkait dengan kelelahan fisik-mental-sosial dan MSDs), pemahaman pekerja terhadap sumber bahaya dan biaya kecelakaan, dan penilaian subjektif kepuasan terhadap beragam fasilitas yang mendukung kegiatan kerja. Secara keseluruhan, terdapat setidaknya 122 pertanyaan (baik kualitatif maupun kuantitatif) yang diajukan kepada hampir seluruh responden. Banyaknya pertanyaan tersebut menyebabkan tidak seluruh responden dapat memberikan informasi secara lengkap karena terlupa atau karena keterbatasan waktu yang tersedia. Selain itu, terdapat beberapa responden 
yang menolak menjawab pertanyaan terkait data finansial dan informasi personal karena alasan pribadi.

Untuk mengoptimalkan akurasi informasi yang digali, data diambil melalui wawancara tatap muka dan pendampingan saat pengisian kuisioner meskipun teknik ini memerlukan biaya yang relatif tinggi dan waktu penelitian yang lebih lama dibanding mempersilahkan responden mengisi kuisioner secara mandiri. Angka partisipasi responden terhadap seluruh bahasan yang diteliti disajikan dalam Tabel 1. Informasi terkait karakteristik dasar responden disajikan pada Tabel 2.

\section{Analisis}

\section{Kelelahan fisik-mental-sosial dan MSDs}

Dalam penelitian ini, kelelahan dinilai melalui pernyataan subjektif (kualitatif) responden yang diperoleh dengan menggunakan teknik penilaian Indeks Gejala Kelelahan Kumulatif (Cumulative Fatigue Symptoms Index; CFSI). CFSI merupakan sebuah instrumen penilaian kelelahan yang mudah digunakan namun akurat yang dikembangkan oleh Kosugo dan Fujii (Kosugo \& Fujii 1987). CFSI memandang kelelahan sebagai sebuah konsep multidimensi yang mencakup tiga dimensi kelelahan yang meliputi dimensi fisik, dimensi mental, dan dimensi sosial yang kemudian diturunkan ke dalam delapan pengelompokan sub-dimensi. Pada 1992 dan 1993, kuesioner CFSI yang telah dikembangkan sebelumnya direvisi dengan menghapus 7 pertanyaan dari 81 pertanyaan (versi awal) sehingga kuisioner hanya terdiri atas 74 pertanyaan saja (Tabel 3; Kosugo et al. 1992; Yoshimura \& Acar 2004). Dalam CFSI, setiap item pertanyaan dijawab dalam pilihan jawaban "ya” atau "tidak”. Kuesioner yang digunakan

Tabel 1. Karakteristik dasar responden

Table 1. Basic characteristics of respondents

\begin{tabular}{|c|c|c|c|c|c|c|}
\hline Pekerjaan & Jumlah & $\begin{array}{l}\text { Jenis kelamin } \\
\left.(\mathrm{P} / \mathrm{L})_{1}\right)\end{array}$ & Pendidikan formal & $\begin{array}{l}\text { Usia (tahun, } \\
\left.\mathrm{M}(\mathrm{SD})_{2}\right) \text { ) }\end{array}$ & $\begin{array}{l}\text { Pengalaman kerja } \\
\text { (tahun) }\end{array}$ & $\begin{array}{l}\text { Rataan penghasilan } \\
\text { (Rp/bulan) }\end{array}$ \\
\hline $\begin{array}{l}\text { Polisi } \\
\text { hutan }\end{array}$ & 15 & $0 / 15$ & $\begin{array}{l}\mathrm{SD}=- \\
\mathrm{SMP}=- \\
\mathrm{SMA}=100 \% \\
\mathrm{PT}=-\end{array}$ & $41(7)$ & $17(6)$ & 3.000 .000 \\
\hline $\begin{array}{l}\text { Pekerja in- } \\
\text { ventarisasi } \\
\text { hutan }\end{array}$ & 15 & $0 / 15$ & $\begin{array}{l}\text { SD }=11 \% \\
\mathrm{SMP}=33 \% \\
\mathrm{SMA}=44 \% \\
\mathrm{PT}=11 \%\end{array}$ & $25(8)$ & $4(4)$ & 2.300 .000 \\
\hline $\begin{array}{l}\text { Pengawas } \\
\text { peneba- } \\
\text { ngan }\end{array}$ & 47 & $\mathrm{o} / 47$ & $\begin{array}{l}\mathrm{SD}=13 \% \\
\mathrm{SMP}=5 \% \\
\mathrm{SMA}=78 \% \\
\mathrm{PT}=5 \%\end{array}$ & $43(7)$ & $9(8)$ & 3.400 .000 \\
\hline $\begin{array}{l}\text { Staf ad- } \\
\text { ministrasi }\end{array}$ & 21 & $2 / 19$ & $\begin{array}{l}\mathrm{SD}=- \\
\mathrm{SMP}=10 \% \\
\mathrm{SMA}=5 \mathbf{2} \% \\
\mathrm{PT}=38 \%\end{array}$ & $36(7)$ & $11(6)$ & 2.3750 .000 \\
\hline
\end{tabular}

Keterangan: 1) $\mathrm{P}$ = perempuan, $\mathrm{L}=$ laki-laki. 2) $\mathrm{M}$ = rata-rata, $\mathrm{SD}=$ deviasi standar

Remarks: 1) $\mathrm{P}$ = female, $\mathrm{L}=$ male. 2) $\mathrm{M}$ = average, $\mathrm{SD}=$ standard deviation

Tabel 2. Angka partisipasi responden

Table 2. Respondent participation rate

\begin{tabular}{|c|c|c|c|c|c|c|}
\hline \multirow[b]{2}{*}{ Kelompok responden } & \multirow[b]{2}{*}{ CFSI } & \multirow[b]{2}{*}{ SNQ } & \multirow{2}{*}{$\begin{array}{l}\text { Kepua- } \\
\text { san kerja }\end{array}$} & \multicolumn{2}{|c|}{ Personal data } & \multirow{2}{*}{$\begin{array}{l}\text { Persepsi terhadap sumber bahaya dan } \\
\text { biaya kecelakaan }\end{array}$} \\
\hline & & & & $\begin{array}{c}\text { Data } \\
\text { umum }\end{array}$ & $\begin{array}{c}\text { Data finan- } \\
\text { sial }\end{array}$ & \\
\hline Polisi hutan & 15 & 7 & 6 & 15 & 6 & 7 \\
\hline Pekerja inventarisasi hutan & 15 & 9 & 10 & 15 & 3 & 8 \\
\hline Pengawas penebangan & 47 & 40 & 31 & 47 & 28 & 20 \\
\hline Staf administrasi & 21 & 21 & 28 & 21 & 2 & 12 \\
\hline TOTAL & 98 & 77 & 75 & 98 & 39 & 47 \\
\hline
\end{tabular}

Keterangan: CFSI = Cumulatif Fatique Symptom Index (Index Gejala Kelelahan Akumulatif); SNQ = Standardized Nordic Questionnaire

Remarks: CFSI = Cumulatif Fatique Symptom Index; SNQ = Standardized Nordic Questionnaire 
dalam penelitian ini mengadopsi kuisioner CFSI versi bahasa Inggris (Yoshimura \& Acar 2004).

Dalam indeks ini, tingkat keluhan dihitung pada tingkat pertanyaan dan tingkat sub-dimensi. Persamaan untuk menghitung tingkat keluhan pada tingkat pertanyaan (Yoshimura \& Acar 2004) adalah:

$$
r_{i}=\frac{y_{i}}{T}
$$

\section{keterangan:}

$$
\begin{aligned}
& r_{i}=\text { tingkat keluhan untuk pertanyaan ke- } i \\
& y_{i}=\text { total jawaban "ya" pada pertanyaan ke- } i \\
& T=\text { total jumlah responden yang berpartisipasi }
\end{aligned}
$$

\begin{tabular}{|c|c|c|c|c|c|}
\hline Subdimensi & No. & Pernyataan & Subdimensi & No. & Pertanyaan \\
\hline \multicolumn{3}{|c|}{ Dimensi kelelahan fisik (physical fatigue) } & \multicolumn{3}{|c|}{ Dimensi kelelahan mental (psychological fatigue) } \\
\hline \multirow{10}{*}{$\begin{array}{l}\text { Kelelahan } \\
\text { umum (10 } \\
\text { pertanyan) }\end{array}$} & 17 & $\begin{array}{l}\text { Saya sangat canggung dan sering men- } \\
\text { jatuhkan barang }\end{array}$ & \multirow{8}{*}{$\begin{array}{l}\text { Pera-saan ce- } \\
\text { mas berlebihan } \\
(11 \text { pertanyaan })\end{array}$} & 45 & Entah bagaimana saya merasa gelisah \\
\hline & 25 & Terkadang saya merasa lemah & & 46 & $\begin{array}{l}\text { Saya tidak bisa puas dengan satu hal karena } \\
\text { banyak hal muncul di pikiran }\end{array}$ \\
\hline & 28 & Saya sering merasa pusing & & 50 & $\begin{array}{l}\text { Saya berpikir bahwa saya lebih rendah dari- } \\
\text { pada orang lain }\end{array}$ \\
\hline & 40 & Saya sakit punggung & & 55 & Saya kesulitan berkonsentrasi \\
\hline & 41 & Saya merasakan sakit di setiap sendi & & 64 & $\begin{array}{l}\text { Saya bermasalah dan ingin memberi tahu } \\
\text { seseorang }\end{array}$ \\
\hline & 53 & Penglihatan saya terkadang redup & & 69 & Saya khawatir tentang hal-hal sepele \\
\hline & 58 & Mata saya lelah & & 72 & $\begin{array}{l}\text { Saya tidak bisa berhenti memikirkan peker- } \\
\text { jaan saya bahkan setelah saya kembali ke } \\
\text { rumah }\end{array}$ \\
\hline & 59 & Saya memiliki bahu yang kaku & & 74 & $\begin{array}{l}\text { Saya sering terlalu bersemangat/ingin untuk } \\
\text { tertidur di malam hari }\end{array}$ \\
\hline & 60 & $\begin{array}{l}\text { Saya tidak bisa tidur nyenyak, dan punya } \\
\text { banyak mimpi }\end{array}$ & \multirow{9}{*}{$\begin{array}{l}\text { Penurunan } \\
\text { vitalitas (9 } \\
\text { pertanyaan) }\end{array}$} & 2 & Saya tidak punya kesabaran \\
\hline & 67 & Akhir-akhir ini kaki saya terasa lelah & & 8 & Saya terlalu malas untuk melakukan apa pun \\
\hline \multirow{8}{*}{$\begin{array}{l}\text { Kelelahan kronis } \\
\text { (8pertanyaan) }\end{array}$} & 9 & Akhir-akhir ini saya merasa sangat mengantuk & & 22 & Saya tidak bisa tenang bekerja \\
\hline & 12 & $\begin{array}{l}\text { Saya sering masih merasa lelah bahkan } \\
\text { ketika saya bangun di pagi hari }\end{array}$ & & 36 & Saya merasa semuanya merepotkan \\
\hline & 30 & $\begin{array}{l}\text { Akhir-akhir ini seluruh tubuh saya terasa } \\
\text { lesu }\end{array}$ & & 43 & $\begin{array}{l}\text { Saya tidak punya energi untuk memikirkan } \\
\text { apa pun }\end{array}$ \\
\hline & 32 & $\begin{array}{l}\text { Saya merasa tidak enak badan ketika ban- } \\
\text { gun di pagi hari }\end{array}$ & & 56 & Saya dengan mudah kehilangan vitalitas \\
\hline & 42 & Saya tidak punya waktu untuk bersantai & & 65 & $\begin{array}{l}\text { Saya tidak memiliki keinginan melakukan } \\
\text { apa yang saya suka }\end{array}$ \\
\hline & 70 & $\begin{array}{l}\text { Saya tidak pulih dari kelelahan setelah } \\
\text { bekerja }\end{array}$ & & 66 & Pikiran saya tidak tajam \\
\hline & 71 & \begin{tabular}{|l|}
$\begin{array}{l}\text { Saya sering merasa sangat lelah sehingga } \\
\text { saya merasa ingin berbaring selama bekerja }\end{array}$ \\
\end{tabular} & & 68 & $\begin{array}{l}\text { Entah bagaimana, saya tidak memiliki } \\
\text { vitalitas }\end{array}$ \\
\hline & 75 & \begin{tabular}{|l|} 
Saya lelah bekerja setiap hari \\
\end{tabular} & Dimensi kelelah & han sc & ial (social fatigue) \\
\hline \multirow{7}{*}{$\begin{array}{l}\text { Gangguan fisik } \\
\text { (7pertanyaan) }\end{array}$} & 1 & Akhir-akhir ini nafsu makan saya berkurang & \multirow{7}{*}{$\begin{array}{l}\text { Lekasmarah/mu- } \\
\text { dahtersinggung (7 } \\
\text { pertanyaan) }\end{array}$} & 3 & Saya terkadang marah karena masalah sepele \\
\hline & 11 & Akhir-akhir ini kepala saya terasa berat & & 7 & Saya merasa tegang \\
\hline & 18 & $\begin{array}{l}\text { Akhir-akhir ini saya tidak bisa tertidur } \\
\text { dengan mudah }\end{array}$ & & 23 & $\begin{array}{l}\text { Saya mudah berteriak dan berbicara dengan } \\
\text { nada suara yang marah }\end{array}$ \\
\hline & 21 & Saya memiliki masalah perut & & 24 & Saya merasa jengkel tanpa alasan \\
\hline & 38 & Terkadang saya merasa sakit dan mual & & 31 & Saya merasa ingin memukuli seseorang \\
\hline & 51 & Saya sering mengalami diare & & 44 & Saya tidak bisa menahan amarah \\
\hline & 80 & $\begin{array}{l}\text { Saya terlalu mengkhawatirkan kesehatan } \\
\text { saya }\end{array}$ & & 54 & $\begin{array}{l}\text { Suara berisik atau suara seseorang meng- } \\
\text { ganggu saya }\end{array}$ \\
\hline \multicolumn{3}{|c|}{ Dimensi kelelahan mental (psychological fatigue) } & \multirow{13}{*}{$\begin{array}{l}\text { Keengganan } \\
\text { untukbekerja (13 } \\
\text { pertanyaan) }\end{array}$} & 6 & Pekerjaan saya terlalu monoton \\
\hline \multirow{9}{*}{$\begin{array}{l}\text { Depresi }(9 \\
\text { pertanyaan) }\end{array}$} & 4 & $\begin{array}{l}\text { Saya merasa tidak ada kesenangan/kebaha- } \\
\text { giaan dalam hidup saya }\end{array}$ & & 13 & Saya tidak puas dengan banyak hal \\
\hline & 15 & Saya terkadang ingin sendirian & & 33 & Saya merasa sulit untuk pergi bekerja di pagi hari \\
\hline & 26 & Saya membenci diri saya sendiri & & 34 & Suasana tempat kerja saya suram \\
\hline & 27 & Saya merasa enggan berbicara & & 37 & Saya sulit bergaul dengan bos saya \\
\hline & 29 & $\begin{array}{l}\text { Saya tidak memiliki kepercayaan diri pada } \\
\text { apa yang telah saya lakukan }\end{array}$ & & 39 & $\begin{array}{l}\text { Saya tidak bisa bergaul dengan sesama } \\
\text { pekerja }\end{array}$ \\
\hline & 35 & Akhir-akhir ini saya mengalami disorientasi & & 48 & Saya tidak punya ambisi untuk bekerja \\
\hline & 52 & $\begin{array}{l}\text { Saya ingin pergi berpesta dan melepaskan } \\
\text { masalah saya }\end{array}$ & & 57 & Saya kehilangan minat pada pekerjaan \\
\hline & 79 & Saya tidak dapat menikmati apa pun & & 63 & Saya tidak punya mimpi untuk masa depan \\
\hline & 81 & Akhir-akhir ini saya merasa suram & & 73 & $\begin{array}{l}\text { Saya tidak ingin meneruskan pekerjaan yang } \\
\text { sekarang }\end{array}$ \\
\hline \multirow{3}{*}{$\begin{array}{l}\text { Pera-saan } \\
\text { cemas ber- } \\
\text { lebihan (11 } \\
\text { pertanyaan) }\end{array}$} & 14 & $\begin{array}{l}\text { Saya punya sesuatu yang perlu dikhawa- } \\
\text { tirkan }\end{array}$ & & 76 & Saya tidak punya apa-apa untuk hidup \\
\hline & 16 & $\begin{array}{l}\text { Terkadang saya merasa tidak nyaman tanpa } \\
\text { alasan tertentu }\end{array}$ & & 77 & Tidak ada semangat dalam hidup saya \\
\hline & 19 & Akhir-akhir ini saya suka melamun & & 78 & Saya merasa tidak ada gunanya berusaha \\
\hline
\end{tabular}

Tabel 3. Daftar pernyataan pada setiap dimensi dan subdimensi pada instrumen penilaian kelelahan Index Gejala Kelelahan Akumulatif (SFSI)

Table 3. List of the statements in each dimension and subdimension in the Cumulative Fatigue Symptoms Index (CFSI) 
Persamaan untuk menghitung tingkat keluhan pada tingkat sub-dimensi (Yoshimura \& Acar 2004) adalah:

$$
R_{i}=\frac{Y_{i}}{K_{i} \mathrm{~T}}
$$

keterangan:

$\mathrm{R}=$ tingkat keluhan pada subdimensi ke- $i$

$\mathrm{Y}=$ total jawaban "ya" pada pertanyaan yang

dikategorikan sebagai sub-dimensi ke- $i$

$\mathrm{T}=$ total jumlah responden yang berpartisipasi

$\mathrm{K}=$ jumlah pertanyaan pada sub-dimensi ke- $i$

Data MSDs diambil dengan mengadopsi metode Standardized Nordic Questionnaire (SNQ; Kuorinka et al. 1987) dengan instrumen berupa gambar tubuh (body map; 14 bagian tubuh) baik tubuh bagian depan dan belakang. Pada gambar tersebut, responden diminta menunjukkan bagian tubuh yang terasa sakit.

Pemahaman responden terhadap sumber bahaya dan biaya kecelakaan

Informasi tentang bagaimana responden memahami konsep sumber bahaya dan konsep biaya kecelakaan dijaring menggunakan metode wawancara (tatap muka, pertanyaan terbuka, semi terstruktur). Pertanyaan yang diajukan adalah:

(1) Jelaskan definisi sumber bahaya menurut pemahaman anda!

(2) Menurut anda, apa saja yang merupakan sumber bahaya di tempat kerja?

(3) Mengapa jawaban pertanyaan nomor 2 tersebut anda kategorikan sebagai sumber bahaya?

(4) Menurut anda, apa bentuk kerugian saat terjadi kecelakaan kerja?

(5) Menurut anda, siapa saja yang akan menanggung kerugian jika terjadi kecelakaan kerja?

Kepuasan fasilitas kerja

Kepuasan fasilitas kerja merepresentasikan persepsi responden terhadap kepuasan mereka atas alat kerja yang digunakan dan yang tersedia saat ini, fasilitas kesehatan, fasilitas pengembangan diri, fasilitas sosial, fasilitas komunikasi, dan aksesibilitas dari camp/tempat tinggal menuju tempat kerja. Fasilitas kesehatan yang dimaksud dalam penelitian ini meliputi asuransi kesehatan dan klinik kesehatan (termasuk alat kesehatan dan obat-obatan yang tersedia) yang terdapat di sekitar camp/tempat tinggal. Fasilitas pengembangan diri yang dimaksud adalah kesempatan responden untuk mengikuti berbagai kursus/program pelatihan, termasuk kesempatan memperoleh kenaikan posisi/jabatan sesuai aturan. Adapun fasilitas sosial yang dimaksud terdiri atas fasilitas umum sarana olahraga dan rumah ibadah. Sedangkan fasilitas komunikasi terdiri atas berbagai sarana yang mendukung komunikasi seperti tersedianya jaringan telepon seluler, komunikasi satelit, ataupun handie talkie untuk berkomunikasi saat tengah bekerja dalam hutan. Adapun aksesibilitas yang dimaksud adalah kemudahan untuk mencapai lokasi kerja dari camp/tempat tinggal yang didukung oleh tersedianya sarana transportasi yang sesuai serta jaringan jalan yang baik. Keenam elemen ini dipilih sebagai tolak ukur tingkat kepuasan kerja karena elemen-elemen tersebut terbukti memiliki hubungan positif yang kuat terhadap kepuasan kerja di kalangan pekerja pada level operator dan sejenisnya (Yovi \& Yamada 2019).

Informasi terkait penilaian kepuasan terhadap fasilitas kerja ditanyakan dalam bentuk jawaban dikotomi "ya" dan "tidak" terhadap pertanyaan:

(1) Apakah anda puas terhadap peralatan kerja saat ini?

(2) Apakah anda puas terhadap fasilitas kesehatan yang tersedia saat ini?

(3) Apakah anda puas terhadap fasilitas pengembangan diri saat ini?

(4) Apakah anda puas terhadap fasilitas sosial saat ini?

(5) Apakah anda puas terhadap fasilitas komunikasi saat ini?

(6) Apakah anda puas terhadap tingkat aksesibilitas dari camp/rumah ke tempat kerja?

Untuk mendukung analisis terhadap kepuasan fasilitas kerja, informasi terkait kondisi finansial dari responden turut digali. Data diambil menggunakan kuisioner dan wawancara (tatap muka, pertanyaan terbuka, semi terstruktur).

\section{Hasil dan Pembahasan}

\section{Kelelahan fisik-mental-sosial}

Dimensi kelelahan yang paling banyak ditemukan pada responden adalah kelelahan fisik (physical 
fatigue) baik pada sub-dimensi kelelahan kronis (chronic fatigue), kelelahan umum (general fatigue), maupun sub-dimensi gangguan fisik (physical disorders) (Tabel 4). Dimensi kelelahan lain yang perlu mendapat perhatian adalah kelelahan mental (psychological fatigue) khususnya sub-dimensi gangguan kecemasan (feeling of anxiety). Gejala kumulatif kelelahan pada tingkatan sub-dimensi untuk setiap jenis pekerjaan disajikan pada Gambar 1

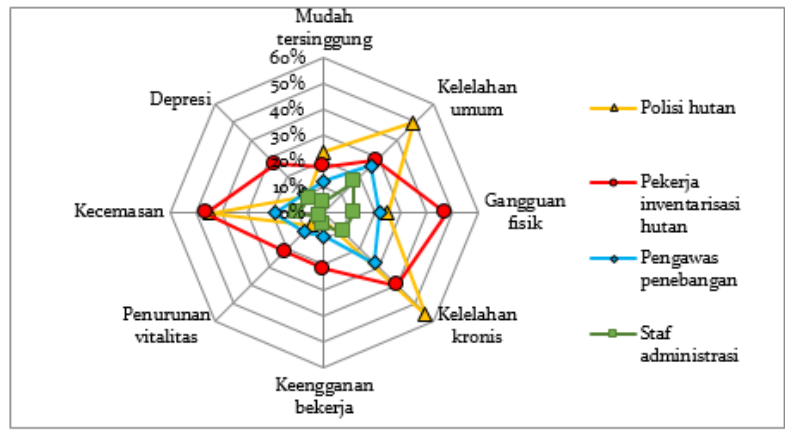

Gambar 1. Gejala kumulatif kelelahan pada tingkatan sub-dimensi untuk setiap jenis pekerjaan

Figure 1. Cumulative symptoms of fatigue at the subdimension level for each type of work

Tabel 4. Hasil Index Gejala Kelelahan Akumulatif (CFSI) pada tingkat keluhan per pertanyaan (r)

Table 4. Results of the Cumulative Fatigue Symptoms Index (CFSI) at the question level ( $\mathrm{r}$ )

\begin{tabular}{|c|c|c|c|c|c|c|}
\hline \multicolumn{3}{|l|}{ Gejala kelelahan } & \multicolumn{4}{|c|}{$\begin{array}{l}\text { Nilai "r" (\%) untuk setiap jenis } \\
\text { pekerjaan }\end{array}$} \\
\hline Dimensi & Subdimensi & Gejala & A & $\mathrm{B}$ & $\mathrm{C}$ & $\mathrm{D}$ \\
\hline \multirow[t]{15}{*}{ Kelelahan fisik } & \multirow{5}{*}{$\begin{array}{l}\text { Kelelahan } \\
\text { umum }\end{array}$} & Saya tidak bisa tidur nyenyak, dan punya banyak mimpi & $100 \%$ & & & \multirow{5}{*}{$43 \%$} \\
\hline & & Akhir-akhir ini kaki saya terasa lelah & $100 \%$ & & & \\
\hline & & Saya sakit punggung & $93 \%$ & $47 \%$ & $64 \%$ & \\
\hline & & Saya memiliki bahu yang kaku & $80 \%$ & & & \\
\hline & & Saya merasakan sakit di setiap sendi & $47 \%$ & & & \\
\hline & \multirow{3}{*}{$\begin{array}{l}\text { Gangguan } \\
\text { fisik }\end{array}$} & Akhir-akhir ini nafsu makan saya berkurang & & $87 \%$ & & \\
\hline & & Akhir-akhir ini saya tidak bisa tertidur dengan mudah & & $73 \%$ & & \\
\hline & & Akhir-akhir ini kepala saya terasa berat & & $53 \%$ & & \\
\hline & \multirow{7}{*}{$\begin{array}{l}\text { Kelelahan } \\
\text { kronis }\end{array}$} & Akhir-akhir ini seluruh tubuh saya terasa lesu & $80 \%$ & & & \\
\hline & & $\begin{array}{l}\text { Saya sering masih merasa lelah bahkan ketika saya bangun di } \\
\text { pagi hari }\end{array}$ & $73 \%$ & $73 \%$ & $47 \%$ & \\
\hline & & $\begin{array}{l}\text { Saya sering merasa sangat lelah sehingga saya merasa ingin } \\
\text { berbaring selama bekerja }\end{array}$ & $60 \%$ & $53 \%$ & $54 \%$ & \\
\hline & & Saya merasa tidak enak badan ketika bangun di pagi hari & $67 \%$ & $80 \%$ & & \\
\hline & & Saya lelah bekerja setiap hari & $60 \%$ & & & \\
\hline & & Saya tidak punya waktu untuk bersantai & $53 \%$ & & & \\
\hline & & Akhir-akhir ini saya merasa sangat mengantuk & $40 \%$ & $47 \%$ & & \\
\hline \multirow[t]{8}{*}{$\begin{array}{l}\text { Kelelahan } \\
\text { mental }\end{array}$} & \multirow{8}{*}{$\begin{array}{l}\text { Perasaan } \\
\text { cemas berlebi- } \\
\text { han }\end{array}$} & $\begin{array}{l}\text { Saya tidak bisa berhenti memikirkan pekerjaan saya bahkan } \\
\text { setelah saya kembali ke rumah }\end{array}$ & $100 \%$ & & & \\
\hline & & Saya punya sesuatu yang perlu dikhawatirkan & $87 \%$ & $93 \%$ & & \\
\hline & & Saya bermasalah dan ingin memberi tahu seseorang & $73 \%$ & $60 \%$ & & \\
\hline & & Saya berpikir bahwa saya lebih rendah daripada orang lain & $67 \%$ & & & \\
\hline & & Terkadang saya merasa tidak nyaman tanpa alasan tertentu & $40 \%$ & $53 \%$ & & \\
\hline & & $\begin{array}{l}\text { Saya sering terlalu bersemangat/ingin untuk tertidur di malam } \\
\text { hari }\end{array}$ & $40 \%$ & $67 \%$ & & \\
\hline & & Entah bagaimana saya merasa gelisah & & $53 \%$ & & \\
\hline & & Saya kesulitan berkonsentrasi & & $60 \%$ & & \\
\hline
\end{tabular}

Catatan: (1) Huruf " $r$ " mewakili tingkat keluhan pada setiap pernyataan (gejala) yang merepresentasikan persen responden yang mengalami gejala kelelahan dimaksud. (2) A: penjaga/polisi hutan; B: pekerja inventarisasi hutan; C: pengawas penebangan; D: staf administrasi. (3) Tabel 4 hanya menyajikan gejala dengan tingkat keluhan $r \geq 40 \%$.

Remarks: (1) The letter " $r$ " represents the level of complaints at each question (symptom) that represents the percent of respondents who experience the symptoms of fatigue. (2) A: forest rangers B: forest inventory workers; C: logging supervisors; D: administrative staff. (3) Table 4 only presents symptoms with a complaint rate $r \geq 40 \%$ 


\section{Polisi hutan}

Kelompok polisi hutan menunjukkan gejala kelelahan yang didominasi oleh kelelahan fisik (terutama pada sub-dimensi kelelahan umum dan kelelahan kronis) dan kelelahan mental (terutama pada sub-dimensi gangguan kecemasan). Gejala terbanyak pada sub-dimensi kelelahan umum ( $R$ $=49 \%$ ) adalah gangguan tidur dan rasa lelah pada kaki (dirasakan oleh seluruh responden), disusul oleh sakit pinggang, kekakuan pada bahu, dan sakit pada seluruh persendian. Rasa sakit pada bagianbagian tubuh ini terverifikasi dari hasil wawancara menggunakan teknik SNQ (Gambar 2).

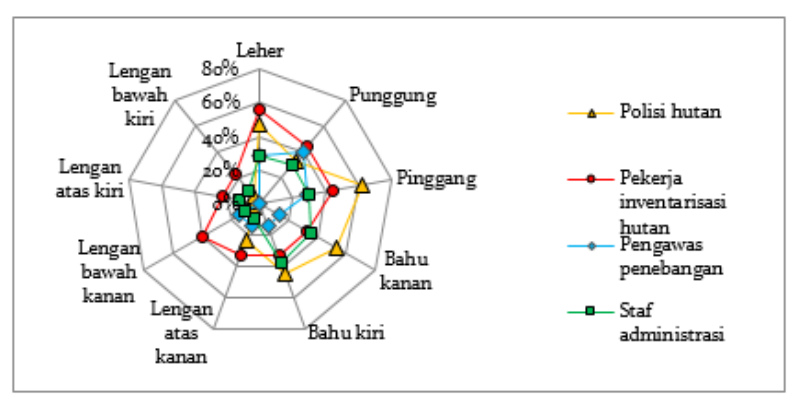

Gambar 2. Keluhan gangguan otot berdasar Standardized Nordic Questionnaire

Figure 2. Complaints of musculoskeletal disorders based on the Standardized Nordic Questionnaire

Kelelahan kronis $(\mathrm{R}=56 \%)$ pada polisi hutan ditemukan dalam bentuk rasa lesu, tetap merasa lelah saat bangun pagi sehingga ingin berbaring meski saat jam kerja, tidak merasa segar walau saat bangun pagi, merasa lelah karena kegiatan harian, merasa tidak memiliki waktu untuk rileks, dan merasa mengantuk sepanjang hari. Adapun kelelahan mental terindikasi pada sub-dimensi gangguan mental berupa perasaan cemas berlebihan $(\mathrm{R}=44 \%)$ dengan gejala sulit untuk mengalihkan pikiran dari masalah pekerjaan, merasa khawatir dan berpikir memiliki masalah yang perlu disampaikan kepada orang lain, merasa rendah diri, merasa tidak tenang tanpa sebab yang jelas, dan berkeinginan dapat tertidur saat malam hari. Meski hanya dirasakan oleh $24 \%$ responden, gangguan kesehatan dalam bentuk kelelahan sosial terlihat pada sub-dimensi mudah tersinggung (irritability). Gejala yang terlihat adalah perasaan tegang dan rasa marah yang mudah tersulut.

Secara keseluruhan, polisi hutan mengalami keluhan kelelahan yang paling intens dibanding ketiga kelompok pekerja lainnya. Namun, intensitas gejala yang dirasakan, terutama pada sub-dimensi kelelahan umum, relatif lebih ringan dibandingkan kelelahan pada sub-dimensi yang sama yang dialami oleh operator chainsaw, sopir logging truck, dan pekerja penyaradan manual (Yovi \& Yamada 2019). Tingkat keluhan pada sub-dimensi kelelahan umum yang ditemukan dalam penelitian ini berada pada angka yang relatif serupa dengan tingkat keluhan rata-rata pekerja kehutanan di Turki (Yoshimura \& Acar 2004). Dalam hal kelelahan kronis, intensitas kelelahan yang dialami penjaga hutan hampir menyamai tingkat kelelahan yang dialami oleh tenaga penyaradan manual $(\mathrm{R}=59 \%)$ dan operator chainsaw ( $\mathrm{R}=54 \%$ ) (Yovi \& Yamada 2019), serta serupa dengan tingginya keluhan pada pekerja kehutanan di Turki (Yoshimura \& Acar 2004).

Temuan yang perlu mendapat perhatian serius adalah intensitas kelelahan mental (dalam bentuk kecemasan) pada polisi hutan ternyata jauh lebih tinggi dibanding pekerja-pekerja pada kelompok operator yang terlibat dalam kegiatan penebangan pohon (Yovi \& Yamada 2019). Kondisi ini tampaknya berkaitan dengan karakter pekerjaan polisi hutan yang berisiko tinggi dengan jam kerja aktual yang tidak tetap. Saat seorang polisi hutan melakukan patroli keamanan hutan, ia berhadapan langsung dengan sumber-sumber bahaya yang beragam (misalnya konfrontasi dengan pencuri yang nekat, kebakaran hutan, sungai berarus deras, binatang buas, dan lain sebagainya). Sumber-sumber bahaya ini berpotensi menyebabkan kejadian/insiden dengan tingkat risiko tinggi. Tingkat risiko menjadi semakin tinggi ketika mereka berkegiatan di daerah terpencil dengan aksesibilitas yang sulit, sarana komunikasi terbatas, dan peralatan kerja yang kurang memadai.

\section{Pekerja inventarisasi hutan}

Seperti halnya polisi hutan, pekerja inventarisasi hutan mengalami berbagai gejala kelelahan yang menunjukkan kelelahan pada dimensi fisik dan mental (Tabel 4, Gambar 1). Bentuk kelelahan yang menonjol dalam kelelahan fisik ditemukan pada sub-dimensi gangguan fisik (physical disorders, $\mathrm{R}=$ 48\%) dengan tiga gejala dominan berupa hilangnya nafsu makan, sulit tidur, dan kepala terasa berat. Intensitas kelelahan pada sub-dimensi gangguan 
fisik ini kurang lebih sama dengan yang dialami oleh kelompok penyarad kayu manual dan operator traktor (Yovi \& Yamada 2019), namun jauh lebih tinggi dibanding rata-rata pekerja kehutanan di Turki (Yoshimura \& Acar 2004).

Kelelahan fisik lain yang ditemukan adalah kelelahan kronis $(\mathrm{R}=40 \%)$ dengan tiga gejala dominan berupa perasaan lelah dan tidak nyaman saat bangun pagi hari, merasa mengantuk sepanjang hari, dan perasaan ingin berbaring saat jam kerja. Kelelahan kronis ini jauh lebih ringan dibanding kelelahan kronis yang dialami oleh operator chainsaw, asisten operator, sopir logging truck, penyarad manual, dan operator traktor (Yovi \& Yamada 2019). Adapun kelelahan mental yang menonjol adalah perasaan cemas $(R=46 \%)$ yang ditandai dengan perasaan khawatir, merasa dalam kesulitan, merasa tidak nyaman tanpa alasan jelas, sangat ingin dapat tidur di malam hari, merasa kurang istirahat, dan sulit berkonsentrasi. Hal ini menunjukkan bahwa perasaan cemas yang dialami pekerja inventarisasi hutan memiliki spektrum yang lebih luas dibanding polisi hutan, dan lebih intens dibanding keluhan yang dirasakan oleh pekerja pada level operator (Yovi \& Yamada 2019).

Kelelahan fisik dan mental yang cukup intens ini kemungkinan disebabkan oleh karakter pekerjaan inventarisasi hutan itu sendiri. Pekerja inventarisasi hutan melakukan setidaknya dua jenis inventarisasi, yakni timber cruising dan Inventarisasi Hutan Menyeluruh Berkala (IHMB). Timber cruising dilakukan dengan intensitas pengambilan contoh (sampling intensity) sebesar 100\%, sedangkan IHMB dilakukan berkala 10 tahunan dengan intensitas pengambilan contoh bervariasi yang tergantung pada keragaman volume (berkisar pada $0.2-0.3 \%$; sampling error 5\%). Namun demikian, informasi yang perlu diambil dalam IHMB lebih komplek dibanding saat timber cruising. Kegiatan IHMB bertujuan mengumpulkan informasi lapangan berupa kelerengan (\%) pada jalur sepanjang 20 $\mathrm{m}$ mulai dari titik awal plot contoh, ketinggian lokasi (m dpl), fisiografi, kondisi tapak khusus, kelas tekstur tanah, jumlah pancang (anakan jenis komersial dengan tinggi $\geq 1,5 \mathrm{~m}$ atau diameter $<10$ $\mathrm{cm}$ ), jumlah tiang (pohon hidup berdiameter 10-20 $\mathrm{cm}$; informasi yang diambil adalah nama jenis, diameter setinggi dada, dan kualitas tajuk pohon), jumlah pohon kecil (pohon kecil berdiameter 20$35 \mathrm{~cm}$; informasi yang diambil adalah nama jenis, diameter setinggi dada, tinggi total pohon, tinggi bebas cabang, kualitas tajuk pohon, dan cacat pada batang), dan pohon besar (diameter lebih dari $35 \mathrm{~cm}$; informasi yang diambil sama dengan pohon kecil ditambahkan dengan informasi kelurusan pohon dan kerusakan batang) (MoEF 2007; Pedoman IHMB). Saat timber cruising, pekerja inventarisasi hutan hanya mengambil data nama jenis, diameter setinggi dada, tinggi bebas cabang, kelerengan lapangan, kondisi tumbuhan bawah, dan kondisi tanah. Selain pencatatan informasi tersebut, pada kedua inventarisasi dilakukan pelabelan pada batang-batang pohon sesuai ketentuan.

Kedua kegiatan yang sarat aktivitas fisik ini dilakukan di lingkungan yang berat. Pohon-pohon dapat saja berdiri di atas tanah rawa berkedalaman $\geq 1 \mathrm{~m}$, memiliki banir hingga ketinggian lebih dari $2 \mathrm{~m}$, atau dikelilingi liana, semak, tumbuhan beracun, berduri tajam, atau memiliki sarang lebah/ serangga yang berbahaya lainnya yang kesemuanya itu menyulitkan pekerja untuk mendekat. Selain itu, pada hutan-hutan alam, inventarisasi dilakukan terus menerus pada jangka waktu tertentu (diatas 2 minggu), ini berarti pekerja masuk dan tinggal semakin jauh di dalam hutan setiap harinya, dan baru keluar dari hutan beberapa minggu kemudian setelah menyelesaikan target pekerjaan. Kondisi ini menyebabkan tingginya tingkat kecemasan terhadap terjadinya serangan binatang buas. Aksesibilitas yang sulit untuk mengevakuasi korban dan untuk membawa korban ke fasilitas kesehatan turut meningkatkan perasaan cemas yang dirasakan pekerja inventarisasi hutan.

\section{Pengawas penebangan}

Dibandingkan polisi hutan dan pekerja inventarisasi hutan, pengawas penebangan terindikasi mengalami keluhan kelelahan yang paling ringan (Tabel 4, Gambar 1). Hanya ditemukan satu keluhan kelelahan fisik pada sub-dimensi kelelahan umum $(\mathrm{R}=26 \%$, dalam bentuk sakit punggung) dan dua keluhan yang mengindikasikan kelelahan kronis ( $R=28 \%$, dalam bentuk rasa lelah saat bangun pagi 
dan ingin berbaring saat jam kerja). Hasil SNQ juga memperlihatkan satu-satunya keluhan serius dari responden kelompok pengawas penebangan berupa rasa sakit pada bagian punggung (Gambar 2).

Dari konteks CFSI, kelelahan yang dirasakan oleh pengawas penebangan ini berada pada tingkat yang sama dengan kelelahan yang dirasakan oleh pekerja persemaian (Yovi \& Yamada 2019). "Ringannya" keluhan kelelahan ini kemungkinan disebabkan oleh kegiatan fisik pengawas penebangan yang relatif lebih ringan dibanding kegiatan seorang polisi hutan maupun pekerja inventarisasi hutan.

\section{Staf kantor/administrasi}

Staf administrasi hanya mengeluhkan satu gejala kelelahan fisik dalam sub-dimensi kelelahan umum $(\mathrm{R}=17 \%)$ dengan gejala keluhan kekakuan otot bahu. Analisis SNQ mengidentifikasi bahwa gangguan tersebut terjadi baik pada bahu kanan maupun kiri (Gambar 2). Hal ini dapat dipahami mengingat pada sebagian besar waktu kerja, staf administrasi menunjukkan postur kerja yang cenderung statis saat melakukan pencatatan atau pengolahan data lapangan di atas meja.

Tingginya tingkat kelelahan berdasar hasil CFSI maupun keluhan gangguan otot berdasar analisis SNQ ini pada dasarnya dapat diartikan sebagai reaksi mental dan fisik yang diakibatkan oleh karakteristik lingkungan kerja (dan karakter pekerjaan itu sendiri). Berpijak pada hasil analisis kelelahan dan gangguan otot, program perlindungan $\mathrm{K}_{3}$ hendaknya diprioritaskan pada polisi hutan dan pekerja inventarisasi hutan. Salah satu contoh strategi yang dapat dilakukan adalah evaluasi dan perbaikan pada aspek Sistem Manajemen Risiko Kelelahan (Fatigue Risk Management System) yang pada dasarnya merupakan bagian dari Sistem Manajemen Keselamatan Kerja (Occupational Safety Management System; Lerman et al. 2012).

\section{Kepuasan fasilitas kerja}

Analisis kepuasan fasilitas kerja menunjukkan sebuah temuan yang menarik. Polisi hutan yang terindikasi mengalami kelelahan fisik, mental, dan sosial yang paling kritis (Tabel 4, Gambar 1) ternyata memiliki tingkat kepuasan kerja yang justru paling tinggi pada seluruh aspek yang ditanyakan (Gambar 3) dibandingkan dengan ketiga kelompok responden lainnya. Sebaliknya, staf administrasi yang hanya memiliki satu gejala pada dimensi kelelahan fisik dan keluhan gangguan otot bahu (Tabel 4, Gambar 2) ternyata memiliki tingkat kepuasan kerja yang sangat rendah, terutama pada aspek alat kerja, fasilitas sosial, dan aksesibilitas (tingkat kepuasan pada ketiganya $\leq 43 \%)$. Wawancara lanjutan mengindikasikan bahwa kondisi anomali ini dipengaruhi oleh penilaian subjektif polisi hutan terhadap lokasi kerja di berbagai unit manajemen hutan di Pulau Jawa. Mereka dapat berangkat ke tempat kerja dan kembali ke tempat tinggalnya setiap hari, bahkan cukup dengan menggunakan kendaraan roda dua. Tempat tinggal mereka relatif tidak terisolir karena berada dekat atau bahkan berada di dalam perkampungan. Kondisi ini menyebabkan mereka merasa sangat puas, sehingga mereka merasa hampir tidak memiliki keluhan berarti terhadap kelima fasilitas lainnya. Hal ini dapat dijelaskan sebagai behavioral plasticity (Brockner 1984), artinya responden memberikan reaksi yang berbeda terhadap suatu aspek eksternal yang sama.

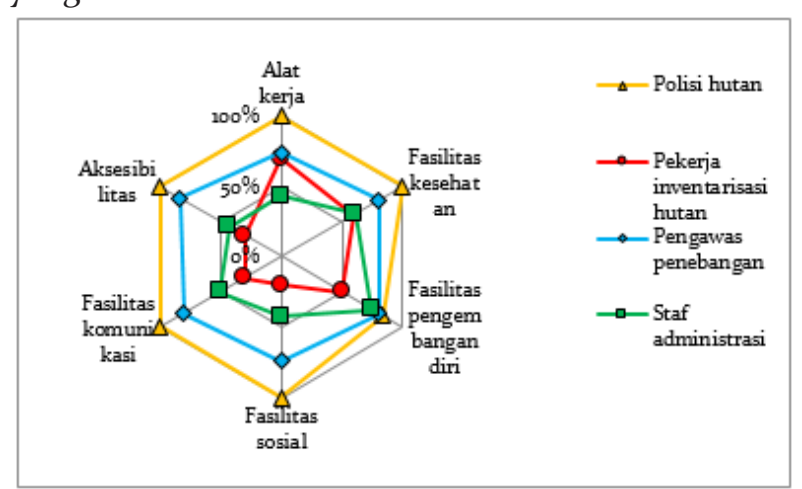

Gambar 3. Tingkat kepuasan saat ini yang dirasakan setiap kelompok responden terhadap enam aspek eksternal

Figure 3. The current level of satisfaction felt by each group of respondents towards the six external aspects

Pengawas penebangan memiliki tingkat kepuasan yang cukup tinggi $(\geq 74 \%$ pada seluruh aspek eksternal yang diukur). Hal ini sejalan dengan hasil CFSI yang menunjukkan keluhan kelelahan yang relatif rendah ( $\leq 28 \%$; Gambar 1). Sedangkan pekerja inventarisasi hutan memiliki tingkat kepuasan kerja yang sangat rendah pada hampir seluruh aspek terutama aspek fasilitas sosial, fasilitas komunikasi, 
dan aksesibilitas (Gambar 3) sejalan dengan tingginya keluhan kelelahan pada analisis CFSI (Gambar 1) dan keluhan gangguan otot pada SNQ (Gambar 2).

Rendahnya tingkat kepuasan kerja pada kalangan pekerja inventarisasi hutan dan staf administrasi tampaknya belum akan memicu berpindahkerjanya kedua kelompok responden (Côté \& Morgan 2002; Applebaum et al. 2010). Hal ini dikarenakan sebagian besar pekerja memiliki tingkat ketergantungan finansial yang sangat besar terhadap pekerjaan di sektor kehutanan. Seluruh responden dari kalangan polisi hutan, inventarisasi hutan, dan staf kantor/ administrasi mendapatkan penghasilan hanya dari pekerjaan mereka saat ini. Sebagian responden pengawas lapangan (41\%) memiliki penghasilan tambahan (12-36\% dari total penghasilan bulanan). Bagian yang dibelanjakan untuk kebutuhan makan pada keempat kelompok responden berada pada kisaran 46\% dari total pendapatan (lihat Tabel 1). Hal ini perlu dipahami sebagai sebuah masalah, mengingat rasio belanja makanan terhadap penghasilan bulanan masih jauh lebih tinggi dari tipikal rasio belanja makanan pada keluarga berpenghasilan rendah (Castner \& Mabli 2010), walau secara umum sedikit lebih baik daripada rasio belanja makanan pada kelompok pekerja operator (Yovi \& Yamada 2019).

Dari sudut pandang ergonomi, rendahnya kepuasan terhadap fasilitas kerja perlu mendapat perhatian serius. Kepuasan terhadap fasilitas kerja yang rendah akan memicu kepuasan kerja yang rendah dan menghasilkan kinerja dan produktivitas kerja rendah (Tumen \& Zeydanli 2016; Shobe 2018), yang keduanya berasosiasi negatif dengan pembangunan iklim keselamatan, padahal iklim keselamatan pada dasarnya merupakan salah satu penentu keberhasilan perlindungan $\mathrm{K}_{3}$ (Gyekye 2005; Arshadi \& Damiri 2013).

\section{Pemahaman terhadap sumber bahaya dan kon- sep biaya kecelakaan kerja}

Kelompok responden pengawas penebangan dan inventarisasi hutan menyebutkan karakteristik pekerjaan, jalanan yang licin, pohon tumbang, tanah yang rawan longsor, patahan dahanranting yang tersangkut di kanopi pohon, mobil tertabrak kendaraan lain, angin, binatang buas, dan serangga (lebah hutan) sebagai bahaya yang perlu dicermati. Selain api kebakaran hutan, polisi hutan menyebutkan bahwa log yang tertinggal dalam hutan sebagai sumber bahaya karena memicu pencurian kayu. Mereka juga menyebutkan bahwa lokasi patroli yang terpencil dengan anggota regu patroli terbatas merupakan sumber bahaya yang harus mereka hadapi setiap menjalankan tugasnya. Adapun kelompok staf administrasi menyebutkan hal-hal yang berkaitan dengan listrik sebagai bentuk sumber bahaya yang mereka kenali dalam lingkungan kerja mereka.

Secara keseluruhan, sebanyak 59\% responden dapat menyebutkan beragam sumber bahaya di sekeliling tempat kerja dengan cukup baik, walau pada dasarnya masih banyak sumber bahaya potensial lainnya yang belum dikenali dengan baik oleh responden. Sumber bahaya yang tidak disadari oleh hamper seluruh responden adalah perilaku kerja tidak sehat dan selamat yang justru banyak dipraktikkan dalam kegiatan sehari-hari, misalnya mengabaikan prosedur operasi yang ditetapkan saat bekerja, abai terhadap perawatan rutin alat kerja, abai terhadap alat pelindung diri saat bekerja, dan lain sebagainya.

Dalam hal biaya kecelakaan, hilangnya pendapatan korban merupakan bentuk kerugian/ biaya akibat kecelakaan kerja yang paling banyak disebutkan (23\% pernyataan), disusul oleh sakit berkepanjangan atau cacat permanen (20\%), kematian (11\%), dan berkurangnya produktivitas kerja akibat terganggunya proses produksi (6\%). Terkait pandangan terhadap pihak yang dirugikan, $48 \%$ responden menyebutkan bahwa pihak yang menanggung kerugian tersebut adalah diri sendiri, $17 \%$ responden menyebutkan perusahaan dan diri sendiri, dan $34 \%$ sisanya menyatakan tidak tahu.

Temuan ini mengindikasikan fakta bahwa sebagian besar responden memiliki pemahaman yang kurang tepat terkait konsep biaya kecelakaan. Responden belum memahami bahwa kerugian bagi perusahaan juga dapat berupa pengeluaran untuk penggajian yang terus diberikan kepada korban selama masa perawatan (bagi karyawan permanen), berkurangnya produktivitas, biaya pelatihan ulang bagi pekerja baru yang menggantikan posisi korban 
(termasuk upah lembur bagi pekerja pengganti), kompensasi kepada korban, biaya perbaikan alat, biaya perawatan korban, biaya perjalanan yang ditimbulkan, dan biaya-biaya lain yang disebabkan adanya upaya kontrol dan pengawasan tambahan. Hrymak \& Pérezgonzález (2007) menyebutkan bahwa tiga pos biaya pertama (yang disebutkan di atas) menghabiskan sebagian besar total biaya kecelakaan (87\%). Dari sisi pekerja/korban, Hrymak \& Pérezgonzález (2007) menyebutkan bahwa biaya kecelakaan kerja yang timbul berupa berkurangnya jumlah penghasilan "normal" yang biasanya dapat diterima korban saat sehat (55\%), hilangnya upah yang semestinya didapatkan dari waktu kerja tambahan (30\%), biaya untuk pengobatan/ perawatan ( $5 \%)$, biaya perjalanan yang timbul dalam rangka pengobatan (4\%), dan biaya lainnya (6\%). Distribusi biaya tersebut menunjukkan bahwa biaya yang timbul akibat kecelakaan kerja tidak hanya berbentuk biaya pengobatan/perawatan, bahkan biaya pengobatan/perawatan hanyalah sebagian kecil dari total biaya kecelakaan.

\section{Strategi Peningkatan Perlindungan $\mathrm{K}_{3}$}

Secara keseluruhan, penelitian ini memberikan indikasi kuat bahwa meskipun hutan terbukti menurunkan tingkat stres dari sisi penerima jasa lingkungan (Shin 2007), namun efek yang ditimbulkan berbanding terbalik terhadap pekerja yang terlibat langsung dalam kegiatan pengelolaan hutan itu sendiri. Penelitian ini menunjukkan bahwa (1) pekerjaan di sektor kehutanan didominasi oleh kegiatan yang menuntut aktivitas fisik berlebih dan tekanan mental yang secara signifikan terbukti membebani pekerjanya dengan risiko gangguan $\mathrm{K}_{3}$ yang tinggi, (2) pekerja di sektor kehutanan masih didominasi oleh pekerja yang memiliki tingkat kemampuan finansial cukup rendah, dan (3) pekerja memiliki tingkat pemahaman terhadap konsep sumber bahaya dan konsep biaya kecelakaan masih kurang tepat. Kombinasi lemahnya kemampuan finansial dan rendahnya aspek kognitif perlindungan $\mathrm{K}_{3}$ tersebut menjadi penghambat upaya peningkatan perlindungan $\mathrm{K}_{3}$ melalui pendekatan partisipatif (Burgess-Limerick 2018). Penelitian ini juga mengungkap fakta bahwa kelengkapan fasilitas pendukung kerja masih perlu ditingkatkan. Kondisi ini pada akhirnya akan berpengaruh negatif pada keberhasilan pencapaian target pengelolaan hutan lestari secara paripurna.

Upayauntukmencapaitujuanbesar"meningkatkan perlindungan $\mathrm{K}_{3}$ pekerja di sektor kehutanan" hendaknya didasari oleh komitmen yang kuat oleh pembuat kebijakan. Termasuk dalam komitmen ini adalah merumuskan kebijakan perlindungan $\mathrm{K}_{3}$ yang sesuai kebutuhan aktual dengan target yang rasional. Data dari berbagai hasil penelitian terkait (research evidence) hendaknya digunakan sebagai salah satu sumber informasi penting dalam menentukan arah dan bentuk rumusan (Orton 2011) karena merumuskan kebijakan dengan hanya mendasarkan pada komitmen dan teori belum menjadi dasar yang kuat dalam membuat keputusan terkait kebijakan publik (Macintyre \& Petticrew 200o).

Saat ini beberapa hasil penelitian terkait gangguan $\mathrm{K}_{3}$ dan aspek ergonomi lainnya di sektor kehutanan di Indonesia telah banyak dilakukan. Penelitian-penelitian tersebut memberikan beragam data dan informasi terkait $\mathrm{K}_{3}$ dan aspek ergonomi lainnya yang diperlukan dalam perumusan kebijakan perlindungan $\mathrm{K}_{3}$. Program-program hendaknya diarahkan pada upaya untuk meningkatkan sarana dan prasarana kerja yang baik langsung maupun tidak langsung akan meningkatkan perlindungan $\mathrm{K}_{3}$ pekerja, meningkatkan pendapatan pekerja (salah satunya melalui perbaikan sistem pengupahan; Yovi \& Yamada 2019), serta meningkatkan aspek kognitif pekerja dalam perlindungan $\mathrm{K}_{3}$ (Yovi \& Yamada 2015; Yovi et al. 2016; Yovi \& Yamada 2019). Bentuk program yang dibuat hendaknya tidak sekedar program yang kinerja keberhasilan pencapaiannya diukur dari sekedar kelengkapan dokumen administratif (Yovi \& Nurrochmat 2018).

\section{Kesimpulan}

Selain mengalami gangguan $\mathrm{K}_{3}$ dalam bentuk kelelahan yang intens (terutama pada dimensi fisik dan mental) serta gangguan otot (terutama pada pinggang, punggung, leher, bahu kanan-kiri, serta lengan kanan dan kiri baik lengan bawah maupun atas), saat ini pekerja sektor kehutanan di Indonesia (dalam penelitian ini terdiri atas polisi hutan, pekerja inventarisasi hutan, pengawas penebangan, dan 
staf kantor/administrasi) bekerja dengan fasilitas pendukung kerja yang dianggap belum sesuai dengan kebutuhan pekerja. Untuk mencapai tujuan "Pengelolaan Hutan Produksi Lestari”, kondisi di atas perlu mendapat perhatian melalui upaya peningkatan perlindungan $\mathrm{K}_{3}$. Upaya ini dapat dilakukan melalui berbagai program perlindungan $\mathrm{K}_{3}$ yang disusun dengan mempertimbangkan keterbatasan aspek kognitif (dalam bentuk kurangnya pemahaman terhadap konsep sumber bahaya serta konsep biaya kecelakaan) dan relatif rendahnya kemampuan finansial pekerja. Program yang dimaksud berupa peningkatan fasilitas pendukung kerja (terutama alat kerja, fasilitas kesehatan, pengembangan diri, sarana sosial dan komunikasi, serta aksesibilitas menuju dan dari tempat kerja) yang dari empat kelompok responden pekerja, kehendaknya diprioritaskan bagi polisi hutan dan pekerja inventarisasi hutan. Program lain yang juga perlu dilakukan adalah (1) peningkatan pendapatan dan (2) pemahaman terhadap konsep sumber bahaya dan konsep biaya kecelakaan. Kedua program tersebut perlu diberikan kepada seluruh kelompok pekerja.

\section{Ucapan Terima Kasih}

Penelitian ini dilakukan atas dukungan dana Penelitian Kerjasama Luar Negeri dan Publikasi Internasional dari Kementerian Riset, Teknologi dan Pendidikan Tinggi Republik Indonesia Tahun Anggaran 2016 dan 2017. Ucapan terima kasih juga disampaikan kepada seluruh enumerator yang sangat membantu dalam proses pengambilan data lapangan.

\section{Daftar Pustaka}

Applebaum D, Fowler S, Fiedler N, Osinubi O, Robson M. 2010. The impact of environmental factors on nursing stress, job satisfaction, and turnover intention. Journal of Nursing Administration 40:323-328.

Arshadi N, Damiri H. 2013. The relationship of job stress with turnover intention and job performance: Moderating role of OBSE. Procedia-Social Behavioral Sciences 84:706-710. DOI: 10.1016/j.sbspro.2013.06.631

Barbosa RP, Fiedler NC, do Carmo FCA, Minette LJ, Silva EN. 2014. Analysis of posture in semi-mechanized forest harvesting in steep areas. Revista Arvore 38(4): 733-738. DOI: 0.1590/So10o-67622014000400016

Brockner J. 1984. Low self-esteem and behavioral plasticity: Some implications for personality and social self-esteem. Journal of Social Behavior and Personality 6:349-36o.

Burgess-Limerick R. 2018. Participatory ergonomics: Evidence and implementation lessons. Applied Ergonomics 68: 289-293. DOI: 10.1016/j.apergo.2017.12.009

Castner L, Mabli J. 2010. Low-income household spending pattern and measures of poverty [Online]. https:// fns-prod.azureedge.net/sites/default/files/SpendingPatterns.pdf. Dialses 25 April 2018.

Gallis C. 2006. Work-related prevalence of musculoskeletal symptoms among Greek forest workers. International Journal of Industrial Ergonomics 36(8):731-736. DOI: 10.1016/j. ergon.2006.05.007

Gyekye SA. 2005. Workers' Perceptions of Workplace Safety and Job Satisfaction. Internatioal Journal of Occupational Safety and Ergonomics 11(3):291-302. DOI: 10.1080/10803548.2005.11076650,

Hignett S, McAntamney L. 20oo. Technical note rapid entire body assessment (REBA). Applied Ergonomics 31(2): (201-205).

Hrymak V, JD Pérezgonzález. 2007. The costs and effects of workplace accidents: Twenty case studies from Ireland. Health and Safety Authority Research Series $02 / 2007$.

Kemm J. 2006. The limitations of 'evidence-based' public health. Journal of Evaluation in Clinical Practice 12(3): 319-324. DOI: 10.1111/j.1365-2753.2006.0o6oo.x

Kosugo R, Fujii H. 1987. An index for rating cumulative fatigue symptoms (CFSI) in different occupations. Journal Science of Labour 63:229-246.

Kosugo R, Fujii H, Hirata A. 1992. Subjective assessment of workload. Revision of the Cumulative Fatigue Symptoms Index. Journal Science of Labour 68:489-502.

Kuorinka I, Jonsson B, Kilbom A, Vinterberg H, Biering-Sørensen F, Andersson G, Jørgensen K. 1987. Standardised Nordic questionnaire for the analysis of musculoskeletal symptoms. Applied Ergonomics 18(3): $233-237$.

Lerman SE, Eskin E, Flower DJ, George EC, Gerson B, Hartenbaum N, Hursh SR, Moore-Ede M. 2012. ACOEM Guidance Statement: Fatigue Risk Management in the Workplace. Journal of Occupational and Environmental Medicine 54(2):231-258.

Macintyre S, Petticrew M. 20oo. Good intentions and received wisdom are not enough. Journal of Epidemioloy and Community Health 54(11):802-803.

KLHK. 2007. Peraturan Menteri Kehutanan RI Nomor: P.34/ Menhut-II/2007 tentang Pedoman Inventarisasi Hutan Menyeluruh Berkala (IHMB) pada Usaha Pemanfaatan Hasil Hutan Kayu pada Hutan Produksi. Kementerian Lingkungan Hidup dan Kehutanan, Jakarta.

Orton L, Lloyd-Williams F, Taylor-Robinson D, O'Flaherty M, Capewell S. 2011. The use of research evidence in public health decision making processes: Systematic review. PLoS ONE 6(7): e21704. DOI: 10.1371/journal. pone.0021704

Rehn B, Nilsson T, Lundström R, Hagberg M, Burström L. 2009. Neck pain combined with arm pain among pro- 
fessional drivers of forest machines and the association with whole-body vibration exposure. Ergonomics 52(10): 1240-1247. DOI: 10.1080/00140130902939889

Shin WS. 2007. The influence of forest view through a window on job satisfaction and job stress. Scandinavian Journal of Forest Research 22(3): 248-253. DOI: 10.1080/02827580701262733

Shobe K. 2018. Productivity driven by job satisfaction, physical work environment, management support and job autonomy. Bussiness and Economics Journal 9(2):351. DOI: 10.4172/2151-6219.1000351

Silva EP, Minette LJ, Sanches ALP, de Souza AP, Silva FL, Mafra SCT. 2014. Prevalence of musculoskeletal symptoms in forest harvesting machine operators. Revista Arvore 38(4): 739-745. DOI: 10.1590/So10o67622014000400017

Tumen S, Zeydanli T. 2016. Social interactions in job satisfaction. International Journal of Manpower 37: 426455 .

UN. 1992. Report of The United Nations Conference on Environment and Development (UNCED) Document A/CONF.151/26 (Vol.III), Forest Principle. http:// www.un.org/documents/ga/confi51/aconfi5126-3annex3.htm. Diakses 30 November 2016.

Yoshimura T, Acar HH. 2004. Occupational safety and health conditions of forestry workers in Turkey. Journal of Forest Research 9:225-232. DOI: 10.1007/s10310004-0078-y

Yovi EY, Nurrochmat DR. 2018. An occupational ergonomics in the Indonesian state mandatory sustainable forest management instrument: A review. Forest Policy and Economics 91:27-35. DOI: 10.1016/j.forpol.2017.11.007

Yovi EY, Yamada Y. 2019. Addressing occupational ergonomics issues in Indonesian forestry: Laborer, operator, or equivalent workers. Croatian Journal of Forest Engineering 40(2): 351-365. DOI: 10.5552/croffe.2019.558.

Yovi EY, Yamada Y. 2015. Strategy to disseminate occupational safety and health information to forestry workers: The felling safety game. Journal of Tropical Forest Science 27(2): 213-221.

Yovi EY, Yamada Y, Zaini MF, Kusumadewi CAY, Marisiana L. 2016. Improving the OSH knowledge of Indonesian forestry workers by using safety game application: Tree felling supervisors and operators. Jurnal Manajemen Hutan Tropika 22(1):75-85. DOI: 10.7226/jtfm.22.1.75.

Yovi EY, Pradjawati W. 2015. High risk posture on motor-manual short wood logging system in Acacia mangium plantation. Jurnal Manajemen Hutan Tropika XXI(1):11-18. DOI: 10.7226/jtfm.21.1.11

Yovi EY, Takimoto Y, Ichihara K, Matsubara C. 2005. A study of workload and work efficiency in timber harvesting by using chainsaw in pine plantation forest in Java Island: Clear cutting operation. Applied Forest Science 14(1):17-26.

Yovi EY, Takimoto Y, Ichihara K, Matsubara C. 2006. A study of workload and work efficiency in timber harvesting by using chainsaw in pine plantation forest in Java Island (2): Thinning operation. Applied Forest Science 15(1):23-31. 